\title{
IMPACT OF HALAL PRODUCTS ON PURCHASE DECISIONS AND CUSTOMER SATISFACTION
}

\section{Kurniawan Yunus Ariyono}

Departement of Management, STIE Widya Gama Lumajang, Lumajang, 67352, Indonesia

E-mail address: ariyonoary45@gmail.com

\section{A R T I C L E I N F O}

Date of entry:

3 August 2020

Revision Date:

7 September 2020

Date Received:

12 September 2020

JEL Code: Z12, M51, J28

\section{A B S T R A C T}

Halal is the main parameter in the product selection process. This provision places limitations on food products to enter the Muslim market. Ensuring that food consumed is halal is the responsibility of every Muslim. To make it easier to find out which food is consumed halal, especially packaged foods, it can be seen from the halal label listed on the food packaging. Labels on food products are very important to note. The purpose of this study is to determine and analyze halal products on purchasing decisions and consumer satisfaction. The population in this study were buyers of AZZA mineral water in Lumajang, as many as 150 buyers. The sampling method used in this study was purposive sampling. Methods of data analysis using Simple Linear Regression. The results of this study indicate that halal products have a significant effect on purchasing decisions and consumer satisfaction of AZZA mineral water in Lumajang.

Keywords: Halal Products, Purchase Decisions, Consumer Satisfaction

Cite this as: Ariyono, K. Y. (2020). IMPACT OF HALAL PRODUCTS ON PURCHASE DECISIONS AND CUSTOMER SATISFACTION. International Journal of Accounting and Management Research, 1(2), 52-57. https://doi.org/ 10.30741/ijamr.v1i2.643

\section{INTRODUCTION}

The population of Muslims around the world is increasing. The Muslim population has reached a quarter of the total world population and is expected to increase by $30 \%$ by 2025 (Roberts 2010). This condition has prompted many countries to start developing a new paradigm that pays attention to halal products, halal treats, and the sharia system. This makes halal certified products have a big market opportunity. The global halal food market potential can grow to 500 billion USD in 2010 (Salman \& Siddiqui, 2011). The number of followers of the Muslim religion also continues to increase along with the increasing population and technological advances that have also contributed to distributing news and information about Muslims to people who still embrace other religions.

A food is said to be halal if it is based on the nature and how to obtain it. Determining halalness is not only in the consumption of food and beverages, but also health products and cosmetics. Analyzing halalness has its own complexities, starting from the initial manufacturing process, the materials used in the manufacture to the end of the product, after which it is formalized as a halal or haram product (Qardhawi, 2006). 
Halal is the main parameter in the product selection process. This provision places limitations on food products to enter the Muslim market. Ensuring that food consumed is halal is the responsibility of every Muslim. To make it easier to find out which food is consumed halal, especially packaged foods, it can be seen from the halal label listed on the food packaging. Labels on food products are very important to note.

Many foods are currently labeled halal, but how big is the public response to the halal labeled halal products. Does the Muslim community pay attention to the halal label and whether the halal label factor is the main reference for the demand for a product.

Current consumer satisfaction with consumers is the impact of the consumption process carried out by consumers. At first, consumers only buy a product, then consumers will only realize whether the product is what they want or not. If consumers like the product that has been purchased, the consumer has felt satisfaction in using the product, and vice versa if the consumer chooses not to reuse or buy the product again, the consumer will feel dissatisfied with the product.

The consequences of customer satisfaction / dissatisfaction are very crucial for businesses, because customers are seen as a dimension of market performance. Increased customer satisfaction has the potential to lead to long-term and short-term sales growth, as well as market share as a result of repeat purchases. Meanwhile, customer dissatisfaction raises a number of risks.

People are now starting to think selectively in choosing a product, so that they will get the uses or benefits they are looking for from a product. In fact, sometimes they don't hesitate to spend more to get quality products. The intense competition will position marketers to always develop and grab market share. So only the company with the best product will grow rapidly, and in the long run that company will be more successful than other companies.

AZZA mineral water is one of the mineral waters in Lumajang Regency. AZZA's drink in the past five years has increased by $80 \%$ of its total production. The increase in consumer demand was offset by the issuance of halal products. Based on the temporary survey, information was obtained. That Lumajang inland consumers still find it difficult to get these products. So that consumers feel less satisfied with these products. This situation is the main basis for continuing research. By looking at the halal side of the product, purchasing decisions and customer satisfaction.

\section{METHODS}

The location of this research was carried out on AZZA mineral water buyers in Lumajang. The time of the research was carried out for approximately one month in July 2020August 2020. In this study the population was buyers of AZZA mineral water in Lumajang, as many as 150 buyers. The sampling method used in this study was purposive sampling. Purposive sampling is a purposive sampling technique determined by the researcher, which is not purely based on the researcher 's subjective criteria, but is based on a specific purpose (purposive) and judgments. The criteria for taking this sample is a minimum of more than 3 times a purchase. The method of data collection is done by interview, questionnaire, and documentation study. The data sources of this research are primary data and secondary data. Methods of data analysis using Simple Linear Regression.

\section{RESULTS AND DISCUSSION}

Respondents in this study were AZZA drinking water consumers in Lumajang. The number of respondents taken was 150 people. In this section the respondents are divided according to gender groups. From the data shows that from 35 respondents, it can be 
seen, namely: 99 people or $66 \%$ of them are men and the remaining 51 people or $34 \%$ are women. The amount of data shows that the dominant consumer of AZZA mineral water in Lumajang is male consumers. In this section the respondents are divided by age group. Based on the description of respondents with an age range between $<20$ years, there are as many as 48 people or $32 \%$, while for respondents with an age range between $21-35$ years there are as many as 77 people or $51 \%$ and for respondents with an age range between $>36$ years are as many as 25 people or $17 \%$. Thus it can be concluded that the respondents in this study were dominated by AZZA drinking water consumers in Lumajang with an age range between 21 - 35 years.

The classical assumption test results related to the normality test show that the data used in this study for the halal product variables, purchase decisions and consumer satisfaction are normal. Thus, the assumption of normality can be fulfilled. Likewise the assumption of multicollinearity, the test results show that all the variables used as predictors of the regression model show quite small VIF values, where all are below 10 and the tollerance value is more than 0.1 . This means that the independent variables used in the study do not show any multicollinearity symptoms, which means that all independent variables in this study are mutually independent variables. The results of the heteroscedasticity test with a scatterplot showed that there was no clear pattern and the dots spread above and below the number 0 on the $Y$ axis, so it can be concluded that heteroscedasticity did not occur. Thus all classical assumptions can be fulfilled.

Table 1. Simple Linear Regression

Halal Products Against Purchasing Decisions

\begin{tabular}{|c|c|c|c|c|c|c|c|c|}
\hline \multirow{2}{*}{\multicolumn{2}{|c|}{ Model }} & \multicolumn{2}{|c|}{$\begin{array}{l}\text { Unstandardized } \\
\text { Coefficients }\end{array}$} & \multirow{2}{*}{$\begin{array}{c}\text { Standardized } \\
\text { Coefficients } \\
\text { Beta }\end{array}$} & \multirow[t]{2}{*}{$\mathbf{T}$} & \multirow[t]{2}{*}{ Sig. } & \multicolumn{2}{|c|}{$\begin{array}{c}\text { Collinearity } \\
\text { Statistics }\end{array}$} \\
\hline & & B & Std. Error & & & & Tolerance & VIF \\
\hline \multirow{2}{*}{1} & (Constant) & 14,003 & 1,202 & & 11,654 & 0,000 & & \\
\hline & Halal Products & 0,172 & 0,072 & 0,194 & 2,402 & 0,018 & 1,000 & 1,000 \\
\hline
\end{tabular}

a. Dependent Variable: Buying decision

Source: Data Processed SPSS (2020)

Table 2. Simple Linear Regression

Halal Products Against Consumer Satisfaction

\begin{tabular}{lcccccccc}
\hline & Model & \multicolumn{2}{c}{$\begin{array}{c}\text { Unstandardized } \\
\text { Coefficients }\end{array}$} & $\begin{array}{c}\text { Standardized } \\
\text { Coefficients }\end{array}$ & t & Sig. & $\begin{array}{c}\text { Collinearity } \\
\text { Statistics }\end{array}$ \\
& B & Std. Error & Beta & & & Tolerance & VIF \\
\hline 1 & $\begin{array}{c}\text { (Constant) } \\
\text { Halal Products }\end{array}$ & 7,301 & 1,544 & & 4,729 & 0,000 & & \\
& 0,715 & 0,092 & 0,537 & 7,748 & 0,000 & 1,000 & 1,000
\end{tabular}

a. Dependent Variable: Customer Satisfaction

Source: Data Processed SPSS (2020)

The $t$ test is used to determine the partially significant effect of the independent variable (halal products) on the dependent variable (purchasing decisions and customer satisfaction). To perform $t$ tests on each independent variable, the results of $t$ tables are needed. The results of $t$ table at a significance level of $5 \%$ with degrees of freedom $(n-2)=$ $150-2=142$, then the obtained t table $= \pm 1.97612$.

The $\mathrm{t}$ test results for variable $\mathrm{X}$ (halal products) obtained the $\mathrm{t}$ value $=1.97612$ with a significance level of 0.018 . By using a significance limit of 0.05 , the table is obtained at \pm 2.402 . This means that $\mathrm{t}$ table $<\mathrm{t}$ count, which means that $\mathrm{HO}$ is rejected and $\mathrm{Ha}$ is accepted. Thus, the first hypothesis can be accepted. In other words, it can be concluded that there is a significant effect of halal products on purchasing decisions.

The $t$ test results for variable $X$ (halal products) obtained the value of $t$ count $=7.748$ with a significance level of 0.000 . By using a significance limit of 0.05 , the t table is obtained 
at \pm 1.97612 . This means that $\mathrm{t}$ table $<\mathrm{t}$ count, which means that $\mathrm{HO}$ is rejected and $\mathrm{Ha}$ is accepted. Thus, the second hypothesis can be accepted. In other words, it can be concluded that there is a significant effect of halal products on consumer satisfaction.

The coefficient of determination (R2) is intended to determine the best level of accuracy in regression analysis, this is shown by the magnitude of the coefficient of determination (R2) between 0 (zero) to 1 (one). To see the coefficient of determination in simple linear regression is to use The value of $R$ Square. From the coefficient of determination (R2), a value can be obtained to measure the amount of the contribution of several $\mathrm{X}$ variables to the fluctuation variation of variable $\mathrm{Y}$ which is usually expressed in percentage. The results of the determination coefficient test (R2) can be seen in the table as follows:

Table 3. Determinant coefficient results

Halal Products Against Purchasing Decisions Model Summaryb

\begin{tabular}{ccccc}
\hline Model & $\mathbf{R}$ & R Square & Adjusted R Square & Std. Error of the Estimate \\
1 & $0,350^{a}$ & 0,194 & 0,187 & 1,90533 \\
\hline
\end{tabular}

a. Predictors: (Constant), Halal Products

b. Dependent Variable: Buying decision

Source: Data Processed SPSS (2020)

From the results of calculations using the SPSS version 21 program, it can be seen that the coefficient of determination (RSquare) obtained is 0.194 . This means that $19.4 \%$ of purchase decisions can be explained by the halal product variable, while the remaining $80.6 \%$ of purchase decisions are influenced by other variables not examined in this study such as buying interest, re-purchase, consumer loyalty and others.

\begin{tabular}{ccccc}
\multicolumn{4}{c}{$\begin{array}{c}\text { Table 4. Determinant coefficient results } \\
\text { Halal Products Against Consumer Satisfaction } \\
\text { Model Summary }\end{array}$} \\
\hline Model & $\mathbf{R}$ & R Square & Adjusted R Square & Std. Error of the Estimate \\
1 & 0,537 a & 0,289 & 0,284 & 2,96844 \\
\hline
\end{tabular}

a. Predictors: (Constant), Halal Products

b. Dependent Variable: Customer Satisfaction

Source: Data Processed SPSS 2020

From the results of calculations using the SPSS version 21 program, it can be seen that the coefficient of determination (RSquare) obtained is 0.289 . This means that $28.9 \%$ of consumer satisfaction can be explained by the halal product variable, while the remaining $71.1 \%$ of customer satisfaction is influenced by other variables not examined in this study such as purchase interest, re-purchase, consumer loyalty and others.

The results of this study indicate that there is a relationship between halal products and purchasing decisions. This explains that halal products contribute to the purchasing decisions of Muslim consumers. This purchasing decision is because consumers sometimes pay less attention and even consumers do not understand or lack information about food products that have included a halal label. For this reason, the government still needs to provide information about this halal label to the public, especially Muslims (Rangkuti, 2010).

The results of this study are in line with the research of (Bulan, 2016), (Hayet, 2019), (Yunitasari \& Anwar, 2019), (Alim et al., 2018) who said that this influence is due to the increasing understanding of consumers about the importance of halal labels on every food and packaged drinks and understand the teachings of Islamic law to not consume foods that are prohibited by Allah SWT and must carry out what has been ordered. The most important thing that respondents must do in making a decision to purchase food and beverage products is the halalness of the product. 
The results of this study indicate that there is a relationship between halal products and consumer satisfaction. This explains that halal products have an effect on consumer satisfaction. The better the consumer's assessment of the product / service, the higher the consumer satisfaction will be (Riyono \& Budiharja, 2016). A customer, if satisfied with the value provided by a product or service, is very likely to be a customer for a long time.

The results of this study are in line with the research of (Hidayat $\&$ Resticha, 2019), (Putri \& Suryoko, 2018), (Tamamah \& Muhid, 2019) who say that consumer satisfaction can shape different consumer behavior in users of a product labeled halal. The contribution of the halal product variable is indeed very small to satisfy consumers, but with the increasing understanding of Muslim consumers about the halalness of a product, consumers are now more observant and thorough in buying a product.

\section{CONCLUSION}

Based on the results of the research and discussion above, several conclusions can be drawn as follows: a) Halal products have a significant effect on the decision to purchase AZZA mineral water in Lumajang. b) Halal products have a significant effect on customer satisfaction AZZA mineral water in Lumajang.

The limitation of this study is that it only examines halal products on purchasing decisions and customer satisfaction of AZZA mineral water in Lumajang, therefore for further researchers it is recommended to conduct research that examines other variables that can affect purchasing decisions and consumer satisfaction. Given that the respondents studied have different characters from other consumers.

\section{REFERENCES}

Alim, S. A., Mawardi, M. K., \& Bafadhal, A. S. (2018). Pengaruh Persepsi Label Halal dan Kualitas Produk Terhadap Keputusan Pembelian Produk Fesyen Muslim ( Survei pada Pelanggan Produk Zoya Muslim di Kota Malang ). Jurnal Administrasi Bisnis, 62(1), 127-134.

Bulan, T. P. L. (2016). Pengaruh Labelisasi Halal terhadap Keputusan Pembelian Sosis di Kuala Simpang Kabupaten Aceh Tamiang. Jurnal Manajemen Dan Keuangan Unsam, 5(1), 431-439.

Hayet. (2019). Pengaruh Labelisasi Halal Terhadap Keputusan Pembelian Produk Kosmetik (Studi Kasus di Kota Pontianak, Kalimantan Barat, Indonesia). Islamiconomic: Jurnal Ekonomi Islam, 10(1), 21-38.

Hidayat, R., \& Resticha, D. (2019). Analisis Pengaruh Variasi Produk dan Labelisasi Halal Terhadap Kepuasan Konsumen Untuk Meningkatkan Minat Beli Ulang Pada Kosmetik Wardah (Studi Pada Konsumen Kosmetik Wardah di Kota Batam). Journal of Business Administration, 3(1), 40-52.

Putri, A. N., \& Suryoko, S. (2018). Pengaruh Labelisasi Halal, Harga Dan Kualitas Produk Terhadap Loyalitas Pelanggan Melalui Kepusan Pelanggan (Studi Pada Konsumen Kosmetik Sariayu Di Kota Semarang). Jurnal Imu Administrasi Bisnis, 7(3), 359369.

Qardhawi, Y. (2006). Halal dan Haram. Robbani Press.

Rangkuti, F. (2010). Strategi Promosi Yang Kreatif dan Analisis Kasus Integrated Marketing Communication. Gramedia Pustaka Utama.

Riyono, \& Budiharja, G. E. (2016). Pengaruh Kualitas, Harga, Promosi dan Brand Image Terhadap Kpeutusan Pembelian Produk Aqua di Kota Pati. Jurnal Stie Semarang, 8(2), 92-121.

Salman, F., \& Siddiqui, K. (2011). An exploratory study for measuring consumers awareness and perceptions towards halal food in Pakistan. Interdisciplinary Journal of Contemporary Research in Business, 3(2), 639-651.

Tamamah, \& Muhid, A. (2019). Kepuasan, Kepercayaan dan Brand Switching Konsumen Produk Kosmetik Berlabel Halal. Jurnal Penelitian Psikologi, 10(2), 36-43. 
Yunitasari, V., \& Anwar, M. K. (2019). Pengaruh Label Halal Terhadap Keputusan Pembelian Produk Makanan Impor Pada Mahasiswa Fakultas Ekonomi Universitas Negeri Surabaya. Jurnal Ekonomi Islam, 2(1), 49-57. 